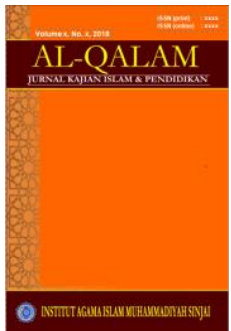

\title{
AL-QALAM
}

Jurnal Kajian Islam \& Pendidikan

Volume 9, No. 1, 2017

ISSN (print) : 1858-4152

ISSN (online) : xxxx-xxxx

Homepage : http://journal.iaimsinjai.ac.id/index.php/al-qalam

\section{IMPLEMENTASI PEMBALAJARAN HOLISTIK DALAM MENINGKATKAN MINAT DAN MOTIVASI BELAJAR SISWA}

\author{
Oleh : Herman Sunusi ${ }^{1}$
}

\begin{abstract}
$* * *$
Abstrak

Konsep dasar pembelajaran holistik (holistic learning) yaitu pendekatan pembelajaran yang berfokus pada pemahaman informasi dan mengkaitkannya dengan topik-topik lain sehingga terbangun kerangka pengetahuan. Manusia juga tidak bisa berdiri sendiri, namun terkait erat dengan lingkungannya. Dalam pembelajaran holistik, diterapkan prinsip bahwa siswa akan belajar lebih efektif jika semua aspek pribadinya (pikiran, tubuh dan jiwa) dilibatkan dalam pengalaman siswa. Konsep dasar minat dan motivasi belajar siswa yaitu minat merupakan potensi psikologi yang dapat dimanfaatkan untuk menggali motif tersebut, apabila seorang peserta didik sudah termotivasi untuk belajar, maka peserta didik tersebut juga akan melakukan aktivitas belajar secara maksimal. Pembalajaran holistik sangat berkontribusi dalam meningkatkan minat dan motivasi siswa karena pembelajaran holistik mengandung kesatuan pendidikan jasmani-rohani, mengasah kecerdasan intelektual-spiritual (emosional)- ketrampilan, kesatuan materi pendidikan teoritis-praktis, kesatuan materi pendidikan pribadi-sosial-ketuhanan.
\end{abstract}

KATA KUNCI : Pembelajaran, Holistik, Motivasi

\section{PENDAHULUAN}

$\mathrm{P}$ embelajaran holistik merupakan suatu filsafat pendidikan yang berangkat dari pemikiran bahwa pada dasarnya seorang individu dapat menemukan identitas, makna dan tujuan hidup melalui hubungannya dengan

${ }^{1}$ Guru Madrasah pada Kementerian Agama Kab. Sinjai 


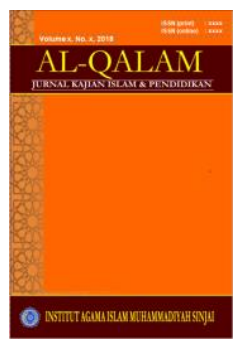

\section{AL-QALAM}

Jurnal Kajian Islam \& Pendidikan

Volume 9, No. 1, 2017

ISSN (print) : 1858-4152

ISSN (online) : xxxx-xxxx

Homepage : http://journal.iaimsinjai.ac.id/index.php/al-qalam

masyarakat, lingkungan alam, dan nilai-nilai spiritual. Melalui pembelajaran holistik siswa mampu mengembangkan seluruh potensi/daya yang ada dalam dirinya sehingga menjadi sumber daya manusia (SDM) yang berkualitas dan potensi/daya yang ada dalam diri siswa yang dapat dikembangkan melalui pendidikan meliputi potensi akademik, potensi fisik, potensi sosial, potensi kreatif, potensi emosi dan potensi spiritual.

Pembelajaran holistik memandang manusia secara utuh, dalam arti manusia dengan unsur kognitif, afeksi dan perilakunya. Manusia juga tidak bisa berdiri sendiri, namun terkait erat dengan lingkungannya. Manusia tidak bisa terlepas dari manusia lain, demikian pula dengan lingkungan fisik atau alam sekitarnya. Manusia juga tergantung kepada Tuhan yang Maha Kuasa selaku pencipta dan penentu hidupnya.

Tujuan pembelajaran holistik adalah membantu mengembangkan potensi individu dalam suasana pembelajaran yang lebih menyenangkan dan menggairahkan, demoktaris dan humanis melalui pengalaman dalam berinteraksi dengan lingkungannya. Melalui pembelajaran holistik, siswa dapat menjadi dirinya sendiri (learning to be). Dalam arti dapat memperoleh kebebasan psikologis, mengambil keputusan yang baik, belajar melalui cara yang sesuai dengan dirinya, memperoleh kecakapan sosial, serta dapat mengembangkan karakter dan emosionalnya. Itulah sebabnya pembelajaran holistik dapat meningkatkan minat dan motivasi belajar siswa. ${ }^{2}$

Pembelajaran holistik dikemas bukan dalam bentuk yang kaku melainkan melalui hubungan langsung antara siswa dengan lingkungannya. Pendekatan Holistik tidak melihat manusia dari aktivitasnya yang terpisah pada bagianbagian tertentu, namun merupakan mahluk yang bersifat utuh dan tingkah

${ }^{2}$ Akhmad Sudrajat, Pendekatan Pembelajaran Holistik di Sekolah Dasar, (Cet. IX., Jakarta: PT Raja Grafindo Persada, 2014), h. 27. 


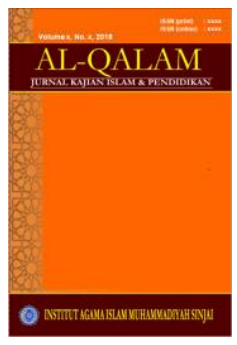

\section{AL-QALAM}

Jurnal Kajian Islam \& Pendidikan

Volume 9, No. 1, 2017

ISSN (print) : 1858-4152

ISSN (online) : xxxx-xxxx

Homepage : http://journal.iaimsinjai.ac.id/index.php/al-qalam

lakunya tidak dapat dijelaskan berdasarkan aktivitas bagian-bagiannya. Tidak hanya melalui potensi intelektualnya saja, namun juga dari potensi spiritual dan emosionalnya

Proses pelaksanaan pembelajaran holistik dalam pendidikan akan mengajak anak berbagi pengalaman kehidupan nyata, mengalami peristiwaperistiwa langsung yang diperoleh dari pengetahuan kehidupan. Dalam pembelajaran lahir kecintaan siswa terhadap pembelajaran, karena pembelajaran holistik mendorong siswa untuk melakukan refleksi, diskusi daripada mengingat secara pasif tentang fakta-fakta. Hal ini jauh lebih bermanfaat meningkatkan minat dan motivasi belajar siswa.

Pembelajaran holistik membantu mengembangkan potensi individu dalam suasana pembelajaran yang lebih menyenangkan dan menggairahkan, demoktaris dan humanis melalui pengalaman dalam berinteraksi dengan lingkungannya. Melalui pembelajaran holistik, siswa dapat menjadi dirinya sendiri (learning to be). Dalam arti dapat memperoleh kebebasan psikologis, mengambil keputusan yang baik, belajar melalui cara yang sesuai dengan dirinya, memperoleh kecakapan sosial, serta dapat mengembangkan karakter dan emosionalnya.

Implementasi pembelajaran holistik tidak lain adalah untuk membangun secara utuh dan seimbang pada setiap siswa dalam seluruh aspek pembelajaran, yang mencakup spiritual, moral, imajinatif, intelektual, budaya, estetika, emosi dan fisik yang mengarahkan seluruh aspek-aspek tersebut ke arah pencapaian sebuah kesadaran tentang hubungannya dengan Tuhan yang merupakan tujuan akhir dari semua kehidupan di dunia.

Melalaui implementasi pembelajaran holistic dapat menciptakan minat dan memotivasi siswa dalam mencapai tujuan, karena salah faktor yang mempengaruhi meningkatnya minat dan motivasi belajar siswa adalah faktor model pembelaharan yang diterapkan. Menurut Achmad Sugandi model 


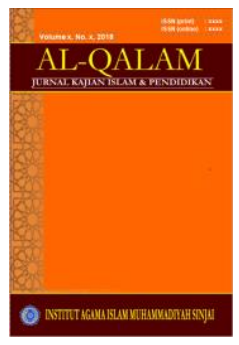

\section{AL-QALAM}

Jurnal Kajian Islam \& Pendidikan

Volume 9, No. 1, 2017

ISSN (print) : 1858-4152

ISSN (online) : xxxx-xxxx

Homepage : http://journal.iaimsinjai.ac.id/index.php/al-qalam

pembelajaran sangat mempengaruhi minat dan motivasi belajar siswa, misalnya model pembelajaran yang digunakan guru kurang baik atau monoton, maka akibatnya siswa tidak semangat dalam belajar, dan minat untuk belajarpun akan menjadi rendah. ${ }^{3}$

Salah satu gagasan dalam meningkatkan minat dan motivasi belajar siswa adalah melalui penerapan pembelajaran holistik (holistik learning), karena dalam pelaksanaannya mendorong terbentuknya model-model pembelajaran alternatif, yang mungkin dalam penyelenggaraannya sangat jauh berbeda dengan pembelajaran pada umumnya, karena dalam pembelajaran holistik, diterapkan prinsip bahwa siswa akan belajar lebih efektif jika semua aspek pribadinya (pikiran, tubuh dan jiwa) dilibatkan dalam pengalaman siswa.

Menciptakan minat juga memiliki hubungan erat dalam meningkatkan motivasi belajar siswa. Fungsi minat merupakan salah satu usaha untuk membimbing perhatian siswa yaitu melalui pemberian ransangan yang menarik perhatian dari siswa.

Meningkatkan minat dan motivasi belajar siswa adalah faktor yang sangat penting dalam proses pembelajaran. The Liang Gie mengatakan: "Minat dan motivasi selain membangkitkan pemusatan pemikiran, juga menimbulkan kegembiraan dalam usaha belajar. Keringanan hati akan memperbesar daya kemampuan belajar seseorang dan juga membantunya untuk tidak mudah melupakan apa yang dipelajari itu. Belajar dengan perasaan yang tidak gembira akan membuat pelajaran itu terasa sangat berat". ${ }^{4}$

Siswa yang menaruh minat dan motivasi pada suatu aktivitas akan memberikan perhatian yang besar. Ia tidak segan mengorbankan waktu dan tenaga

\footnotetext{
${ }^{3}$ Achmad Sugandi, Teori Pembelajaran (Cet. V; Semarang: UPT UNNES, 2007), h 53.

${ }^{4}$ The Liang Gie, Cara Belajar yang Efektif (Yogyakarta : Universitas Gaja Mada, 1980), h. 12 .
} 


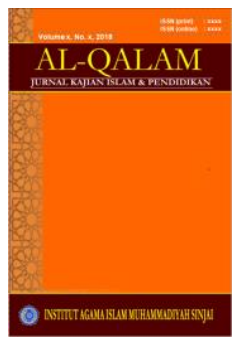

\section{AL-QALAM}

Jurnal Kajian Islam \& Pendidikan

Volume 9, No. 1, 2017

ISSN (print) : 1858-4152

ISSN (online) : xxxx-xxxx

Homepage : http://journal.iaimsinjai.ac.id/index.php/al-qalam

demi aktivitas tersebut. menurut Winkel, W.S. Penting meningkatkan minat dan motivasi belajar siswa, karena berfungsi: (a) Minat dan motivasi melahirkan perhatian yang serta merta. Perhatian yang serta merta terjadi secara spontan, bersifat wajar mudah bertahan dan tumbuh tanpa pemakaian daya kemauan dalam diri seseorang; (b) Minat dan motivasi memudahkan tercapainya konsentrasi. Minat memudahkan tercapainya konsentrasi dalam pikiran seorang siswa yaitu pemusatan pikiran terhadap suatu pelajaran. Jadi tanpa adanya minat maka konsentrasi terhadap pelajaran juga sulit di kembangkan dan di pertahankan; (c) Minat dan motivasi mencegah gangguan dari luar Seorang siswa akan mudah terganggu perhatiannya dan sering mengalihkan perhatiannya ke suatu hal yang lain kalau minat studinya rendah; (d) Minat dan motivasi memperkuat pelekatnya bahan pelajaran dalam ingatan. Pengingatan seorang siswa itu hanya akan terlaksana kalau siswa berminat terhadap pelajarannya; (e) Minat dan motivasi memperkecil kebosanan studi dalam diri sendiri. ${ }^{5}$

Siswa melakukan aktivitas belajar karena ada yang mendorongnya. Dalam hal ini motivasi sebagai dasar penggeraknya yang mendorong seseorang untuk belajar, dan minat merupakan potensi psikologi yang dapat dimanfaatkan untuk menggali motivasi. Adanya minat dan motivasi belajar siswa, maka akan lebih mengenal dan memahami materi pembelajaran, siswa akan tertarik untuk mengemukakan pendapatnya. Siswa berani tampil, bersungguh-sungguh, bersemangat dalam proses pembelajaran dan dapat mencurahkan segenap perasaan, sehingga timbul minat dan motivasi dalam pembelajaran.

Siswa yang tidak memiliki minat dan motivasi belajar biasanya kurang memiliki perhatian dalam proses pembelajaran, biasanya ditunjukkan menjadi anak yang tidak bergembira, tidak bersungguh-sungguh, tidak berani tampil, takut

${ }^{5}$ Winkel, W.S. Psikologi Pendidikan dan Evaluasi Belajar (Cet. XIII; Jakarta: Gramedia, 2004), h. 99. 


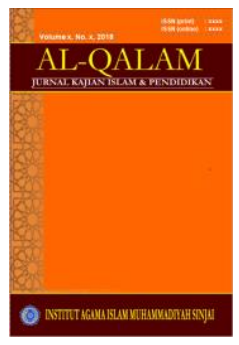

\section{AL-QALAM}

Jurnal Kajian Islam \& Pendidikan

Volume 9, No. 1, 2017

ISSN (print) : 1858-4152

ISSN (online) : xxxx-xxxx

Homepage : http://journal.iaimsinjai.ac.id/index.php/al-qalam

bertanya, itulah pertanda bahwa siswa tidak memiliki minat untuk belajar. Untuk mencapai suatu prestasi, seorang siswa memerlukan minat dan motivasi. Disinilah tugas guru tidak hanya memperhatikan seberapa cerdasnya siswa akan tetapi bagaimana cara membangkitkan minat dan motivasi belajar siswa sehingga memiliki minat dan motivasi untuk mengikuti proses pembelajaran.

Berdasar data empiris di beberapa sekolah ditemukan, bahwa (1) dalam pelaksanaan pembelajaran guru tidak menantang siswa untuk menemukan kembali informasi dari berbagai sumber pembelajaran; (2) Pelaksanaan pembelajaran terbatas hanya siswa mendegarkan saja disaat guru menyampaikan materi sehingga siswa merasa jenuh dalam mengikuti kegiatan pembelajaran.; (3) konsep pembelajaran hanya ditekankan kepada siswa dalam hal hafalan, sementara materi yang diajarakan menuntut siswa untuk mengadakan eksprimen dalam menggunakan alat peraga; (4) guru kurang menerapkan model pembelajaran secara bervariasi.

Akibatnya siswa kurang berminat dan tidak meningkat motivasi belajarnya. Jika masalah tersebut tidak segerah diatasi maka akan berdampak buruk bagi siswa terutama pada mutu dan tatanan aplikasi hasil belajar siswa tidak terlaksana dalam kehidupan masyarakat. Menurut penulis perlu segera dilakukan pengkajian dan dianalisis, mengapa dan faktor apa yang menjadi penyebab kondisi tersebut di atas sampai terjadi.

\section{PERMASALAHAN}

Berdasarkan latar belakang di atas maka yang menjadi pokok masalah pada karya ilmiah ini adalah implementasi pembalajaran holistik dalam meningkatkan minat dan motivasi siswa. Agar pembahasan lebih mendalam, penulis merumuskan beberapa sub masalah yang menjadi pusat perhatian dalam penulisan ini, sebagai berikut: 


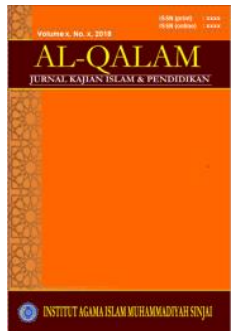

\section{AL-QALAM}

Jurnal Kajian Islam \& Pendidikan

Volume 9, No. 1, 2017

ISSN (print) : 1858-4152

ISSN (online) : xxxx-xxxx

Homepage : http://journal.iaimsinjai.ac.id/index.php/al-qalam

1. Bagaimana konsep dasar pembelajaran holistik?

2. Bagaimana konsep dasar minat dan motivasi belajar siswa?

3. Bagaimana kontribuasi pembalajaran holistik dalam meningkatkan minat dan motivasi siswa?

\section{METODE PENELITIAN}

Penelitian ini berbentuk penelitian kepustakaan (Library Research). Dalam penenlitian ini, peneliti menggunakan metode analisis deskriptif, analisis deskriptif adalah suatu metode dengan mengumpulkan data, mesnyusun atau mengklasifikasi, menganalisis dan menginterpretasikannya. Dengan tahapan-tapan sebagai berikut:

1. Mengumpulkan sumber referensi yang berkaitan dengan masalah yang diteliti serta memperlajarainya.

2. Setelah sumber referensi terkumpul diklasifikasikan data yang terdapat pada obyek penelitian dengan landasan teori yang telah diperoleh dari sumber-sumber referensi.

3. Membaca untuk memperoleh data yang dibutuhkan kemudian diklasifikasikan sesuai denganm sifat yang diperoleh.

4. Kemudian dilakukan proses analisa mengenai topik permasalahan yang diteliti.

\section{PEMBAHASAN}

\section{Konsep Dasar Pembelajaran Holistik}

\section{a). Pengertian Pembelajaran}

Kata pembelajaran mengacu pada pengertian pembelajaran pada pasal 1 ayat 20 Undang-undang RI nomor 20 tahun 2003 tentang Sistem Pendidikan 


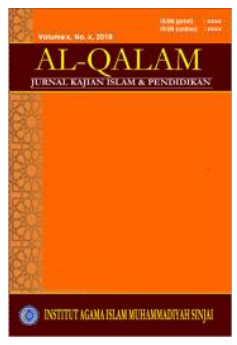

\section{AL-QALAM}

Jurnal Kajian Islam \& Pendidikan

Volume 9, No. 1, 2017

ISSN (print) : 1858-4152

ISSN (online) : xxxx-xxxx

Homepage : http://journal.iaimsinjai.ac.id/index.php/al-qalam

Nasional bahwa "pembelajaran adalah prosesinterksi siswa dengan pendidikdan sumber belajar pada suatu lingkungan belajar". ${ }^{6}$

Kata pembelajaran, dasar katanya adalah belajar yang merupakan aktivitas yang dilakukan seseorang atau siswa secara pribadi dan sepihak. Kata belajar kemudian dibubuhi awalan "pe" dan akhiran "an", menjadi pembelajaran yang berarti proses yang melibatkan dua pihak yaitu guru dan siswa, yang didalamnya mengandung dua unsur sekaligus, yaitu mengajar dan belajar (teaching and learning) ${ }^{7}$

Pembelajaran adalah suatu proses yang kompleks, tidak hanya sekedar menanamkan pengetahuan kepada siswa tetapi banyak hal yang dilakukan pendidik sehingga menyebabkan terjadinya perubahan tingkah laku siswa. ${ }^{8}$ Abdul Madjid menyatakan bahwa pembelajaran dapat diartikan sebagai suatu proses yang dilakukan oleh pendidik dalam membimbing, membantu, dan mengarahkan siswa untuk memiliki pengalaman belajar. ${ }^{9}$

Muhaimin menyatakan bahwa pembelajaran terkait dengan bagaimana (how to) membelajarkan siswa atau bagaimana membuat siswa dapat belajar dengan mudah dan terdorong oleh kemampuannya sendiri untuk mempelajari apa (what to) yang teraktualisasikan dalam kurikulum sebagai kebutuhan (needs) siswa. ${ }^{10}$ Pembelajaran adalah sutau kegiatan guru secara terprogram dalam desain

${ }^{6}$ Republik Indonesia, ”Undang-undang RI. Nomor 20 Tahun 2003 Tentang Sistem Pendidikan Nasional", dalam Redaksi Sinar Grafika (Cet. 1; Jakarta : Sinar Grafika, 2003), h. 107.

${ }^{7}$ Trianto, Mendesain Pembelajaran Kontesktual di Kelas (Cet. I; Jakarta: Cerdas Pustaka Publisher, 2008), h. 9.

${ }^{8}$ Basyiruddin Usman, Metodologi Pembelajaran Agama Islam (Cet. I; Jakarta: Ciputat Pers, 2002), h. 21.

${ }^{9}$ Abdul Madjid, Perencanaan Pembelajaran (Mengembangkan Standar Kompetensi Pendidik) (Cet. I; Bandung: Rosda Karya, 2005), h. 16.

${ }^{10}$ Muhaimin, et al, Paradigma Pendidikan Islam, Upaya Mengefektifkan Pendidikan Agama Islam di Sekolah (Cet. III; Bandung: Remaja Rosda Karya Offset, 2004), h. 146. 


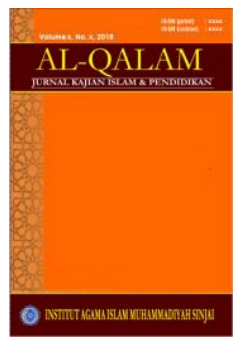

\section{AL-QALAM}

Jurnal Kajian Islam \& Pendidikan

Volume 9, No. 1, 2017

ISSN (print) : 1858-4152

ISSN (online) : xxxx-xxxx

Homepage : http://journal.iaimsinjai.ac.id/index.php/al-qalam

instruksional, untuk membantu siswa belajar secara aktif yang menekankan pada penyediaan sumber belajar. ${ }^{11}$

Pembelajaran suatu usaha guru membentuk tingkah laku yang diinginkan dengan menyediakan lingkungan (stimulus) dan guru memberikan kesempatan kepada siswa untuk berpikir agar dapat mengenal dan memahami apa yang sedang dipelajari yang menekankan pada kemampuan kognisi (mengenal) pada individu yang belajar, karena proses pembelajaran di dalamnya terdapat unsur manusiawi yaitu guru dan siswa.

Pembelajaran adalah suatu kombinasi yang tersusun meliputi unsur-unsur manusiawi, material, fasilitas, perlengkapan, dan prosedur yang saling mempengaruhi mencapai tujuan pembelajaran. ${ }^{12}$ Unsur-unsur manusiawi yang terlibat dalam sistem pengajaran terdiri atas siswa, guru, dan tenaga kependidikan lainnya, misalnya tenaga administrasi dan tenaga laboratorium.

\section{b). Pengertian Holistik}

Kata holistik berasal dari kata whole yang berarti menyeluruh. Pendidikan merupakan suatu bentuk pendidikan yang bertujuan untuk membangun dimensi manusia, yaitu untuk membangun seluruh dimensi sosial, emosional, motorik, akademik, spiritual, dan kognitif sehingga membentuk insan kamil. ${ }^{13}$

Pembelajaran holistik adalah suatu pendekatan pembelajaran yang membangun manusia secara keseluruhan dan utuh dengan mengembangkan

\footnotetext{
${ }^{11}$ Dimyati dan Mudjiono, Belajar dengan Pendekatan Baru (Cet. II; Bandung: Remaja Rosdakarya, 2009), h. 297.

${ }^{12}$ Muhaimin, op.cit., h. 57.

${ }^{13}$ Halida, Penerapan Model Networked (jejaring) dalam Pembelajaran Terpadu Pendidikan Anak Usia Dini, (Cet. VII; Pontianak: Ilmu Pendidikan FKIP UNTAN, 2015), h. 521.
} 


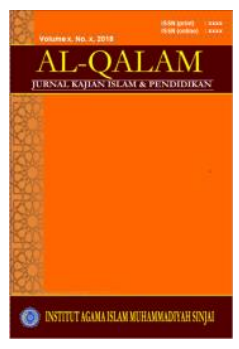

\section{AL-QALAM}

Jurnal Kajian Islam \& Pendidikan

Volume 9, No. 1, 2017

ISSN (print) : 1858-4152

ISSN (online) : xxxx-xxxx

Homepage : http://journal.iaimsinjai.ac.id/index.php/al-qalam

semua potensi manusia yang mencakup potensi sosial-emosional, potensi intelektual, potensi moral (karakter), kreatifitas, dan spiritual. Tujuan pendidikan holistik adalah untuk membentuk manusia holistik.

Pembalajaran holistik menurut Jeremy Henzell-Thomas yang dikutip oleh Halida pembelajaran holistik merupakan suatu upaya membangun secara utuh dan seimbang pada setiap siswa dalam seluruh aspek pembelajaran, yang mencakup spiritual, moral, imajinatif, intelektual, budaya, estetika, emosi dan fisik yang mengarahkan seluruh aspek-aspek tersebut ke arah pencapaian sebuah kesadaran tentang hubungannya dengan Tuhan yang merupakan tujuan akhir dari semua kehidupan di dunia. ${ }^{14}$

Menurut Akhmad Sudrajat pembelajaran holistik (holistik learning) adalah pendekatan pembelajaran yang berfokus pada pemahaman informasi dan mengkaitkannya dengan topik-topik lain sehingga terbangun kerangka pengetahuan. Dalam pembelajaran holistik, diterapkan prinsip bahwa siswa akan belajar lebih efektif jika semua aspek pribadinya (pikiran, tubuh dan jiwa) dilibatkan dalam pengalaman siswa. ${ }^{15}$

Pembelajaran holistik merupakan pendekatan pembelajaran yang berfokus pada pemahaman informasi dan mengkaitkannya dengan topik-topik lain sehingga terbangun kerangka pengetahuan. Pembelajaran holistik memperhatikan kebutuhan dan potensi yang dimiliki siswa, baik dalam aspek intelektual, emosional, emosional, fisik, artistik, kreatif, dan spritual. Proses pembelajaran menjadi tanggung jawab personal sekaligus juga menjadi tanggung jawab kolektif, oleh karena itu strategi pembelajaran lebih diarahkan pada bagaimana mengajar dan bagaimana orang belajar.

\footnotetext{
${ }^{14}$ Ibid., h. 524.

${ }^{15}$ Akhmad Sudrajat, op.cit., h. 27.
} 


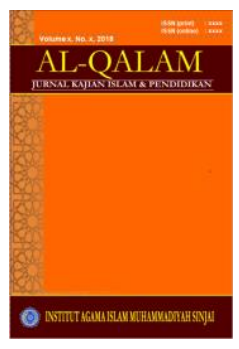

\section{AL-QALAM}

Jurnal Kajian Islam \& Pendidikan

Volume 9, No. 1, 2017

ISSN (print) : 1858-4152

ISSN (online) : xxxx-xxxx

Homepage : http://journal.iaimsinjai.ac.id/index.php/al-qalam

Pembelajaran holistik memperhatikan kebutuhan dan potensi yang dimiliki siswa, baik dalam aspek intelektual, emosional, emosional, fisik, artistik, kreatif, dan spritual. Proses pembelajaran menjadi tanggung jawab personal sekaligus juga menjadi tanggung jawab kolektif, oleh karena itu strategi pembelajaran lebih diarahkan pada bagaimana mengajar dan bagaimana orang belajar. Beberapa hal yang harus dipertimbangkan dalam mengembangkan strategi pembelajaran holistik, diantaranya: (1) menggunakan pendekatan pembelajaran transformatif; (2) prosedur pembelajaran yang fleksibel; (3) pemecahan masalah melalui lintas disiplin ilmu, (4) pembelajaran yang bermakna, dan (5) pembelajaran melibatkan komunitas di mana individu berada.

Dalam pendidikan holistik, peran dan otoritas guru untuk memimpin dan mengontrol kegiatan pembelajaran hanya sedikit dan guru lebih banyak berperan sebagai sahabat, mentor, dan fasilitator. Peran guru seperti seorang teman dalam perjalanan yang telah berpengalaman dan menyenangkan.

Pembelajaran holistik berlandaskan pada pendekatan inquiry dimana anak dilibatkan dalam merencanakan, bereksplorasi dan berbagi gagasan. Anak-anak didorong untuk berkolaborasi bersama teman-temannya dan belajar dengan "cara" mereka sendiri. Anak-anak diberdayakan sebagai si pembelajar dan mampu mengejar kebutuhan belajar mereka melalui tema-tema yang dirancang. Namun ini tidak berarti bahwa peran guru menjadi kurang penting. Guru tetap penting karena sebagai fasilitator ia harus membimbing murid dalam mengusahakan informasi, melakukan seleksi terhadap informasi yang masuk dalam jumlah besar sesuai dengan keperluannya serta menggunakan informasi itu untuk mengembangkan dirinya. Akan tetapi pembentukan dan pendidikan guru harus mengalami perubahan sebagai akibat perubahan peran itu. 


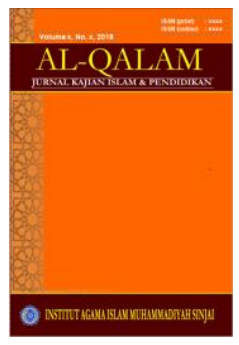

\section{AL-QALAM}

Jurnal Kajian Islam \& Pendidikan

Volume 9, No. 1, 2017

ISSN (print) : 1858-4152

ISSN (online) : xxxx-xxxx

Homepage : http://journal.iaimsinjai.ac.id/index.php/al-qalam

Sebuah pembelajaran yang holistik hanya dapat dilakukan dengan baik apabila pembelajaran yang akan dilakukan alami-natural-nyata-dekat dengan diri anak, dan guru yang melaksanakannya memiliki pemahaman konsep pembelajaran terpadu dengan baik. Selain itu juga dibutuhkan kreativitas dan bahan-bahan/sumber yang kaya serta pengalaman guru dalam berlatih membuat model-model yang tematis juga sangat menentukan kebermaknaan pembelajaran.

\section{c). Kelebihan dan Kekurangan Pembelajaran Holistik}

1. Kelebihan pembelajaran holistic

a. Segala sesuatu yang dipelajari anak merupakan unit yang bertalian erat, bukan yang terlepas satu sama lain.

b. Murid dihadapkan pada masalah yang berarti dalam kehidupan manusia

c. Pembelajaran ini akan memungkinkan hubungan yang erat antara sekolah dan masyarakat

d. Aktivitas anak-anak meningkat karena dirangsang untuk berfikir sendiri dan bekerja sendiri, atau bekerjasama dengan kelompok

e. Pelajaran mudah disesuaikan dengan minat kesanggupan dan minat murid. ${ }^{16}$

Kelebihan dari model ini secara alami sangat proaktif, dengan inisiatif pembelajaran sendiri mencari dan mengikuti ideide baru yang muncul. Pembelajaran distimulasi dengan informasi yang relevan, ketrampilan atau konsep-konsep yang akan dilakukannya nanti. Akan tetapi, kelebihan dari model ini tidak dapat dipaksakan pada pembelajaran, teteapi harus diberikan dari

\footnotetext{
${ }^{16}$ Halida, loc.cit. h. 546.
} 


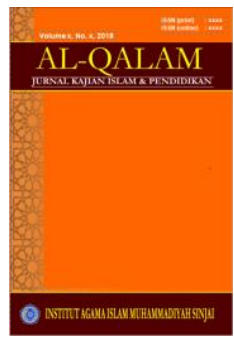

\section{AL-QALAM}

Jurnal Kajian Islam \& Pendidikan

Volume 9, No. 1, 2017

ISSN (print) : 1858-4152

ISSN (online) : xxxx-xxxx

Homepage : http://journal.iaimsinjai.ac.id/index.php/al-qalam

dasar dahulu. Namun demikian, mentor dapat menyediakan modelmodel yang dibutuhkan untuk mendukung tahap-tahap pembelajaran yang kompleks.

2. Kekurangan dari kurikulum holistik

a. Masih banyak guru belum siap untuk melaksanakan kurikulum ini

b. Memberatkan tugas guru

c. Tidak memungkinkan adanya tujuan umum, sebab tidak ada unformitas di sekolah-sekolah antara satu dengan yang lainnya

d. Pada umumnya kondisi sekolah masih kekurangan alat-alat untuk melaksanakan pembelajaran ini. ${ }^{17}$

Kekurangan model ini sangat mudah terjadi bentrokan antara ide dengan ide yang lain. Model ini juga memungkinkan untuk memperoleh lebih dari yang kita pikirkan. Ide-ide tertentu tampak menarik dan bermanfaat, namun tiba-tiba jadi terlalu banyak. Hal ini mengakibatkan manfaaatnya tidak lagi banyak dari jerih payah yang telah dibuat. Kelemahan lainnya dari model ini adalah, jika dilakukan dengan ekstrem, dapat menyebabkan minat menjadi lemah dan mencairkan semangat mental anak.

\section{Konsep Dasar Minat dan Motivasi Belajar Siswa}

\section{a. Pengertian Minat Belajar}

Minat merupakan salah satu aspek psikis yang ada pada setiap manusia yang bersifat relatif. Apabila seseorang menaruh minat terhadap sesuatu, maka

\footnotetext{
${ }^{17}$ Ibid., h. 546.
} 


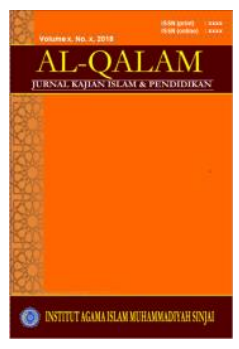

\section{AL-QALAM}

Jurnal Kajian Islam \& Pendidikan

Volume 9, No. 1, 2017

ISSN (print) : 1858-4152

ISSN (online) : xxxx-xxxx

Homepage : http://journal.iaimsinjai.ac.id/index.php/al-qalam

orang tersebut akan berusaha dengan sekuat mungkin untuk memperoleh yang diinginkan. Oleh sebab itu, minat besar sekali pengaruhnya terhadap kegiatan seseorang. Untuk lebih mudahnya ada beberapa pengertian tentang minat.

Menurut Hilgard dalam Slameto minat adalah interest is persisting tendency to pay attention to and enjoy some activity or content (minat adalah kecenderungan yang tetap untuk memperhatikan dan mengenang beberapa kegiatan). Kegiatan yang diminati seseorang, akan diperhatikan terus menerus yang disertai dengan rasa senang. ${ }^{18}$

Pengertian di atas menggambarkan bahwa minat merupakan kecenderungan subyek yang menetap untuk merasa tertarik pada bidang studi atau pokok bahasan tertentu dan merasa senang mempelajari materi pelajaran. Dalam hubungannya dalam belajar antara senang dan berperasaan terdapat hubungan timbal balik. Jika siswa merasa senang untuk mempelajari sesuatu maka akan dapat dengan mudah untuk memahami apa yang telah dipelajarinya, sehingga dapat memperoleh prestasi belajar yang menyenangkan.

Sardiman berpendapat bahwa minat dapat diartikan sebagai suatu kondisi yang terjadi apabila seseorang melihat ciri-ciri atau arti sementara situasi yang dihubungkan dengan keinginan-keinginan atau kebutuhan-kebutuhannya sendiri yang dilakukan dengan kesadaran. ${ }^{19}$

Berdasarkan pendapat tersebut minat merupakan kesadaran seseorang suatu soal atau suatu situasi yang mengandung sangkut paut dengan dirinya. Minat harus dipandang sebagai sesuatu yang sadar, jika tidak maka minat tidak mempunyai arti sama sekali. Oleh karena itu pengetahuan atau informasi tentang

\footnotetext{
${ }^{18}$ Slameto, Belajar dan Faktor-faktor yang Mempengaruhinya (Cet. IV; Jakarta: PT. Rineka Cipta, 2003), h. 57.

${ }^{19}$ Sardiman A.M., Interaksi dan Motivasi Belajar Mengajar (Cet. IX; Jakarta: CV. Rajawali, 2001), h. 76.
} 


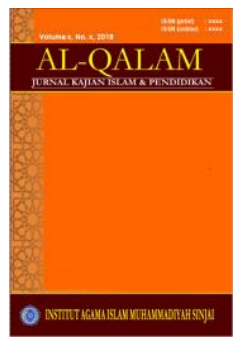

\section{AL-QALAM}

Jurnal Kajian Islam \& Pendidikan

Volume 9, No. 1, 2017

ISSN (print) : 1858-4152

ISSN (online) : xxxx-xxxx

Homepage : http://journal.iaimsinjai.ac.id/index.php/al-qalam

seseorang atau suatu obyek pasti harus ada lebih dahulu dari pada minat terhadap orang atau obyek. Siswa harus merasa sadar bahwa informasi tentang pelajaran yang akan diberikan oleh gurunya di kelas yang mereka sukai mereka harus mengetahui terlebih dahulu.

Dari definisi yang dikemukakan di atas maka dapat diasumsikan bahwa minat adalah kecenderungan seseorang terhadap obyek atau sesuatu kegiatan yang digemari yang disertai dengan perasaan senang, dengan adanya perhatian dan keaktifan. Dalam belajar diperlukan suatu pemusatan perhatian agar yang dipelajari dapat dipahami, sehingga dapat melakukan sesuatu yang sebelumnya tidak dapat dilakukan, terjadilah suatu perubahan kelakukan.

Perubahan kelakuan ini meliputiu seluruh pribadi siswa, baik kognitif, psikomotor maupun afektif. Untuk meningkatkan minat, maka proses pembelajaran dapat dilakukan dalam bentuk kegiatan siswa bekerja dan mengalami apa yang ada di lingkungan secara berkelompok. Menurut Getzel dalam Deppennas, minat adalah suatu disposisi yang terorganisir melalui pengalaman yang mendorong seseorang untuk memperoleh objek khusus, aktivitas, pemahaman, dan keterampilan untuk tujuan perhatian atau pencapaian. ${ }^{20}$

Suatu minat dapat diekspresikan melalui suatu pernyataan yang menunjukkan bahwa siswa lebih menyukai suatu hal daripada hal lainnya, dapat pula dimanifestasikan melalui partisipasi dalam suatu aktivitas. Siswa yang memiliki minat terhadap subyek tertentu cenderung untuk memberikan perhatian yang lebih besar terhadap subyek tersebut. Minat tidak dibawa sejak lahir, melainkan diperoleh kemudian.

${ }^{20}$ Deppennas. Perangkat Penilaian Pembelajaran (Cet. I; Jakarta: Badan Pengembangan Sumber Daya Manusia Pendidikan dan Kebudayaan dan Penjaminan Mutu Pendidikan, 2008), h. 4. 


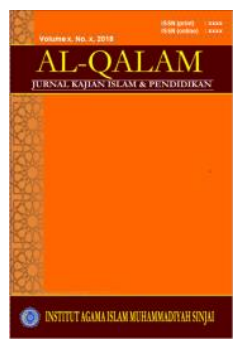

\section{AL-QALAM}

Jurnal Kajian Islam \& Pendidikan

Volume 9, No. 1, 2017

ISSN (print) : 1858-4152

ISSN (online) : xxxx-xxxx

Homepage : http://journal.iaimsinjai.ac.id/index.php/al-qalam

Mengembangkan minat terhadap sesuatu pada dasarnya adalah membantu siswa melihat bagaimana hubungan antara materi yang diharapkan untuk dipelajari dengan dirinya sendiri sebagai individu. Proses ini berarti menunujkkan pada Siswa bagaimana pengetahuan atau kecakapan tertentu mempengaruhi dirinya, melayani tujuan-tujuannya, memuaskan kebutuhan-kebutuhannya. Bila Siswa menyadari bahwa belajar merupakan suatu alat untuk mencapai beberapa tujuan yang dianggapnya penting, dan bila Siswa melihat bahwa hasil dari pengalaman belajarnya akan membawa kemajuan pada dirinya kemungkinan besar ia akan berminat untuk mempelajarinya.

Dalam hal pembelajaran, bahan ajaran dan penyampaian sedapat mungkin disesuaikan dengan minat dan kebutuhan anak tersebut. Pembelajaran perlu memperhatikan minat dan kebutuhan, sebab keduanya akan menjadi penyebab timbulnya perhatian. Sesuatu yang menarik minat dan dibutuhkan anak, tentu akan menarik perhatiannya, dengan demikian mereka akan bersungguh-sungguh dalam belajar.

Minat terhadap sesuatu dipelajari dan mempengaruhi belajar selanjutnya serta mempengaruhi penerimaan minat-minat baru. Jadi minat terhadap sesuatu merupakan hasil belajar dan menyokong belajar selanjutnya. Mengembangkan minat terhadap sesuatu pada dasarnya adalah membantu siswa melihat bagaimana hubungan antara materi yang diharapkan untuk dipelajari dengan dirinya sendiri sebagai individu. Proses ini berarti menunujkkan pada siswa bagaimana pengetahuan atau kecakapan tertentu mempengaruhi dirinya, melayani tujuantujuannya, memuaskan kebutuhan-kebutuhannya.

Bila siswa menyadari bahwa belajar merupakan suatu alat untuk mencapai beberapa tujuan yang dianggapnya penting, dan bila Siswa melihat bahwa hasil dari pengalaman belajarnya akan membawa kemajuan pada dirinya kemungkinan besar ia akan berminat untuk mempelajarinya. Dalam hal pembelajaran, bahan 


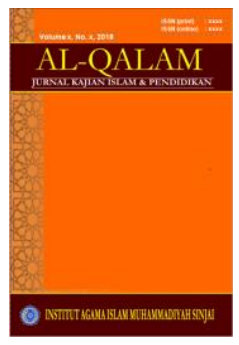

\section{AL-QALAM}

Jurnal Kajian Islam \& Pendidikan

Volume 9, No. 1, 2017

ISSN (print) : 1858-4152

ISSN (online) : xxxx-xxxx

Homepage : http://journal.iaimsinjai.ac.id/index.php/al-qalam

ajaran dan penyampaian sedapat mungkin disesuaikan dengan minat dan kebutuhan anak tersebut.

\section{b. Pengertian Motivasi}

Istilah motivasi berasal dari kata "motif", yakni sebagai daya upaya yang mendorong seseorang untuk melakukan sesuatu. Motif dapat dikatakan sebagai daya penggerak dari dalam dan di dalam subjek untuk melakukan aktivitasaktivitas tertentu demi mencapai suatu tujuan. ${ }^{21}$ Motivasi dapat diartikan sebagai daya penggerak yang telah menjadi aktif. Motif menjadi aktif pada saat-saat tertentu, terutama bila kebutuhan untuk mencapai tujuan sangat dirasakan mendesak.

Dalam Kamus Bahasa Indonesia dijelaskan bahwa kata motivasi memiliki beberapa pengertian, yakni (1) dorongan yang timbul pada diri seseorang secara sadar untuk melakukan suatu tindakan dengan tertentu; (2) usaha yang dapat menyebabkan seseorang atau kelompok orang tertentu tergerak melakukan sesuatu karena ingin mencapai tujuan yang dikehendakinya atau mendapat kepuasan dengan perbuatannya. ${ }^{22}$

Motivasi mengandung tiga elemen penting yaitu: pertama, motivasi itu mengawali terjadinya perubahan energi pada diri setiap individu manusia; kedua motivasi ditandai dengan munculnya "rasa" afeksi seseorang; dan ketiga motivasi akan dirangsang karena adanya tujuan. Motivasi akan menyebabkan terjadinya suatu perubahan energi yang ada pada diri manusia, sehingga akan bergayut dengan persoalan gejala kejiwaaan, perasaan, dan juga emosi, untuk kemudian

${ }^{21}$ Sardiman, op.cit., h. 71.

${ }^{22}$ Departemen Pendidikan dan Kebudayaan, Kamus Besar Bahasa Indonesia, Edisi III (Cet. II; Jakarta: Balai Pustaka, 2002), h. 756 


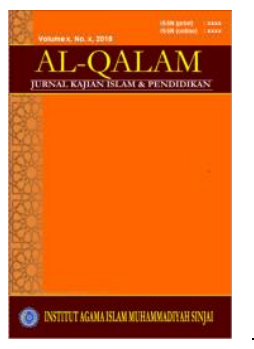

\section{AL-QALAM}

Jurnal Kajian Islam \& Pendidikan

Volume 9, No. 1, 2017

ISSN (print) : 1858-4152

ISSN (online) : xxxx-xxxx

Homepage : http://journal.iaimsinjai.ac.id/index.php/al-qalam

bertindak atau melakukan sesuatu. Semua ini didorong karena adanya tujuan kebutuhan atau keinginan.

Berdasarkan motif ini, maka motivasi dapat diartikan sebagai dorongan yang terdapat dalam diri seseorang untuk berbuat sesuatu perubahan pada dirinya agar menjadi lebih baik dalam memenuhi kebutuhan-kebutuhannya. Olehnya itu, setiap perbuatan pada umumnya disebabkan oleh adanya motivasi. Adanya motivasi karena seseorang merasakan adanya kebutuhan dan untuk mencapai tujuan tertentu. Bila tujuan tercapai, puaslah seseorang dan boleh jadi memberi motivasi lebih lanjut untuk melakukan sesuatu yang lebih berarti dari sebelumnya dalam pencapaian tujuan seseorang.

1. Motivasi dimulai dari adanya perubahan energi dalam pribadi. Perubahan tersebut terjadi disebabkan oleh perubahan tertentu pada sistem neurofisiologis dalam organisme manusia, misalnya terjadinya perubahan dalam sistem pencernaan maka timbul motif.

2. Motivasi ditandai timbulnya perasaan (affective arousal). Mula-mula berupa ketegangan psikologis, lalu berupa suasana emosi. Suasana emosi ini menimbulkan tingkah laku yang bermotif. Perubahan ini dapat diamati pada perbuatannya. Contoh: ada orang yang sementara diskusi, sementara dia tertarik pada permasalahan yang didiskusikan sehingga dia berusaha mengemukakan pendapatnya dengan kata-kata lancar dan tepat.

3. Motivasi ditandai oleh reaksi-reaksi untuk mencapai tujuan. Pribadi yang bermotivasi memberikan respon-respon ke arah suatu tujuan tertentu. Respon-respon ini berfungsi mengurangi ketegangan yang disebabkan oleh perubahan energi dalam dirinya. Tiap respon merupakan suatu langkah ke arah untuk pencapaian tujuan. Contoh: si A mau juara satu di kelasnya maka si A ini harus belajar dengan sungguh-sungguh. Dengan 


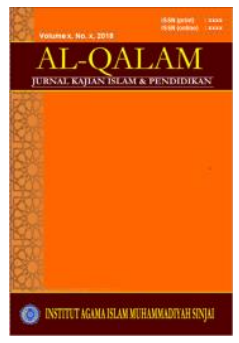

AL-QALAM

Jurnal Kajian Islam \& Pendidikan

Volume 9, No. 1, 2017

ISSN (print) : 1858-4152

ISSN (online) : xxxx-xxxx

Homepage : http://journal.iaimsinjai.ac.id/index.php/al-qalam

motivasi dilandasi oleh adanya kebutuhan. Kebutuhan ini adalah kecenderungan-kecenderungan permanen dalam diri seseorang yang menimbulkan dorongan melakukan suatu perbuatan/tindakan untuk mencapai tujuan. ${ }^{23}$

Istilah motivasi berasal dari kata motif yang dapat diartikan sebagai kekuatan yang terdapat dalam diri individu yang menyebabkan individu tersebut bertindak atau berbuat. ${ }^{24}$ Motivasi dapat dipahami sebagai pemberian motif. Seseorang ingin bekerja karena didasari oleh suatu motif. Motif tersebut terkait dengan maksud dan tujuan yang ingin diraihnya. Pada umumnya motif utama para pekerja untuk melakukan suatu pekerjaan adalah mencari penghasilan, mengembangkan potensi diri, aktualisasi, serta kebutuhan akan penghargaan.

Motivasi adalah daya penggerak dalam diri seseorang untuk melakukan aktivitas tertentu, demi mencapai tujuan tertentu. ${ }^{25}$ Berarti motivasi berkaitan dengan kekuatan dan arah perilaku dan faktor-faktor yang mempengaruhi seseorang untuk berprilaku dengan cara tertentu. Istilah Motivasi dapat merujuk kepada berbagai tujuan yang dimiliki oleh individu, atau cara dimana individu memilih tujuan, atau cara dimana orang lain mencoba merubah perilaku mereka.

Motivasi dapat dikatakan sebagai kondisi intern sebagai dorongan mental yang menggerakkan dan mengarhkan siswa untuk belajar. ${ }^{26}$ Motivasi dapat didefinisikan sebagai suatu alasan yang merupakan daya penggerak (motor) untuk h. 106.

${ }^{23}$ Oemar Hamalik, Kurikulum dan Pembelajaran (Cet. IV; Jakarta: Bumi Aksara, 2003),

${ }^{24}$ Zakiah Daradjat dkk., Ilmu Pendidikan Islam (Cet. V; Jakarta: Bumi Aksara, 2004), h. 16.

${ }^{25}$ Herminarto Sofyan dan Hamzah B. Uno, Teori Motivasi dan Aplikasinya dalam Penelitian (Cet. II; Gorontalo: Nurul Jannah, 2004), h. 5.

${ }^{26}$ Abdul Haling, Belajar dan Pembelajaran (Cet. I; Makassar: Badan Penerbit Universitas negeri Makassar, 2006), h. 98. 


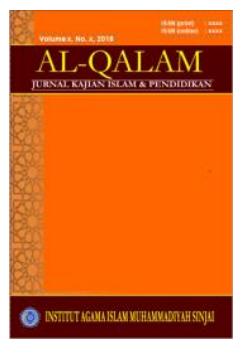

\section{AL-QALAM}

Jurnal Kajian Islam \& Pendidikan

Volume 9, No. 1, 2017

ISSN (print) : 1858-4152

ISSN (online) : xxxx-xxxx

Homepage : http://journal.iaimsinjai.ac.id/index.php/al-qalam

suatu perbuatan atau aktivitas yang timbul dari dalam atau di dalam pribadi seseorang untuk melakukan suatu aktivitas tertentu dalam arah pencapaian rasa puas yang membawa kabahagiaan secara jasmani dan rohani.

Suryabrata mengatakan bahwa motivasi adalah keadaan dalam pribadi orang yang mendorong perilaku individu untuk melakukan aktivitas tertentu untuk mencapai suatu tujuan. Motivasi adalah suatu kegiatan yang terdapat dalam diri organisme yang menyebabkan organisme bertindak dan berbuat, dan dorongan itu lahir dari kekuatan seseorang, kekuatan pendorong inilah yang disebut motif. ${ }^{27}$

Motivasi menjelaskan apa yang membuat orang melakukan sesuatu, membuat mereka tetap melakukannya, dan membantu mereka dalam menyelesaikan tugas-tugas. Hal ini berarti bahwa konsep motivasi digunakan untuk menjelaskan keinginan berperilaku, arah perilaku (pilihan), intensitas perilaku (usaha, berkelanjutan), dan penyelesaian atau prestasi yang sesungguhnya.

Ada tiga komponem utama dalam memotivasi yaitu: (1) kebutuhan; (2) dorongan; (3) tujuan. ${ }^{28}$ Kebutuhan terjadi bila individu merasa ada ketidak seimbangan antara apa yang ia miliki dan yang ia harapkan. Contoh siswa merasa bahwa hasil belajarnya rendah sementara ia memiliki buku pelajaran yang cukup lengkap, ia memiliki banyak waktu namun ia tidak dapat mengatur waktu belajarnya dengan baik. Ia membutuhkan hasil belajarnya dengan baik, sehingga ia berusaha mengubah kebiasaan belajarnya sehingga ia mampu memperoleh hasil belajar yang baik. Disini terlihat bahwa dorongan merupakan kekuatan mental yang sangat menentukan tindakan yang dilakukan dalam memenuhi tujuan yang

\footnotetext{
${ }^{27}$ Suryabrata, Psikologi pendidikan (Cet. XI., Jakarta : PT Raja Grafindo Persada, 2002), h. 227 .

${ }^{28}$ Dimyati dan Mudjiono, op.cit., h. 80.
} 


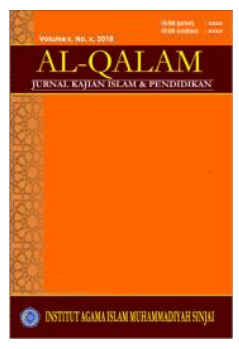

\section{AL-QALAM}

Jurnal Kajian Islam \& Pendidikan

Volume 9, No. 1, 2017

ISSN (print) : 1858-4152

ISSN (online) : xxxx-xxxx

Homepage : http://journal.iaimsinjai.ac.id/index.php/al-qalam

diharapkan. Jadi motivasi merupakan kekuatan mental yang berorientasi pada pemenuhan harapan atau pencapaian tujuan.

Berdasarkan hal di atas motivasi dapat dimaknai sebagai dorongan mental dalam diri seseorang siswa karena suatu perubahan energi pada dirinya yang ditandai oleh timbulnya perasaan atau keinginan atau kebutuhan dan reaksi atau tindakan/perbuatan dalam mencapai tujuan yang berdampak pada perubahan tingkah laku.

Bertolak dari pengertian motivasi siswa di atas, maka dapat mengantar kepada pemahaman atau pengertian motivasi siswa yakni sebagai keseluruhan daya penggerak di dalam diri siswa yang menimbulkan kegiatan pembelajaran yang menjamin kelangsungan dari kegiatan pendidikan.

Dikatakan keseluruhan karena pada umumnya ada beberapa motif yang bersama-sama menggerakkan siswa untuk menjalankan tugasnya. Peranannya yang khas dalam hal penumbuhan motivasi/gairah, merasa senang dan bersemangat untuk melaksanakan tugas. Siswa yang memiliki motivasi yang kuat akan mempunyai banyak energi untuk melakukan kegiatan belajar.

Konsep motivasi sebagaimana yang disebutkan diatas, sebagai penggerak tingkah laku individu untuk melakukan tingkah laku tertentu. Motivasi mempunyai ciri-ciri umum, yaitu: (1) motivasi itu menggerakkan terjadinya perilaku, (2) motivasi dapat mengarahkan atau menyalurkan perilaku kearah suatu tujuan, (3) motivasi itu mengarahkan bagaimana perilaku itu berawal, dipertahankan dan dihentikan.

Pengertian motivasi yang disebutkan di atas, terkait juga dengan persoalan minat. Minat diartikan sebagai suatu kondisi yang terjadi apabila seseorang melihat ciri-ciri atau arti sementara situasi yang dihubungkan dengan keinginankeinginan atau kebutuhan-kebutuhan-nya sendiri. Oleh karena itu, apa yang dilihat seseorang sudak tentu akan membangkitkan minatnya sejauh apa yang dilihat itu 


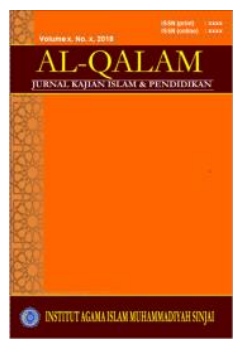

AL-QALAM

Jurnal Kajian Islam \& Pendidikan

Volume 9, No. 1, 2017

ISSN (print) : 1858-4152

ISSN (online) : xxxx-xxxx

Homepage : http://journal.iaimsinjai.ac.id/index.php/al-qalam

mempunyai hubungan dengan kepentingannya sendiri. Hal ini menunjukkan bahwa minat merupakan kecenderungan jiwa seseorang kepada seseorang (biasanya disertai dengan perasaan senang), karena itu merasa ada kepentingan dengan sesuatu itu.

Motivasi itu menunjukkan intensitas idividu, arah dan ketekunan dari upaya menuju pencapaian tujuan. Sementara motivasi dalam pengertian yang umum berkaitan dengan upaya untuk mencapai tujuan baik tujuan individu maupun tujuan organisasi. Motivasi secara luas bahwa motivasi sebagai atribut yang menggerakkan seseorang untuk melakukan atau tidak melakukan sesuatu.

Motivasi merupakan kesediaan untuk melaksanakan upaya tinggi untuk mencapai tujuan-tujuan pendidikan yang dikondisikan oleh kemampuan upaya untuk memenuhi kebutuhan individual tertentu. Sedangkan Luthans memandang motivasi sebagai suatu sistem yang terdiri dari:

1. Kebutuhan, bahwa kebutuhan diciptakan setiap kali ada ketidak seimbangan psikologis dan fisiologis

2. Dorongan, adalah suatu pendorong atau motif yang dibentuk untuk mengurangi kebutuhan.

3. Insentif, adalah sesuatu yang akan meringan kebutuhan dan mengurangi adanya dorongan. ${ }^{29}$

Beberapa pendapat tentang motivasi sebagaimana telah diuraikan di atas, dapat disimpulkan, bahwa yang dimaksud dengan motivasi siswa adalah suatu perilaku dan faktor-faktor yang mempengaruhi siswa untuk berprilaku terhadap pekerjaannya. Motivasi kerja merupakan proses yang menunjukkan intensitas individu, arah dan ketekunan sebagai upaya untuk mencapai tujuan individu dan tujuan pendidikan.

\footnotetext{
${ }^{29}$ Bower Luthans, Motivation-Requiretment Hirarchy By Maslow. Mcgraw-Hill Inc.
} Tokyo, 2005), h. 99. 


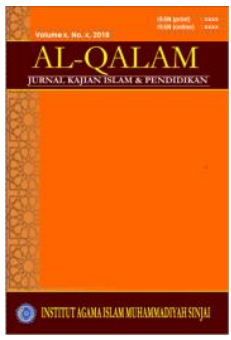

\section{AL-QALAM}

Jurnal Kajian Islam \& Pendidikan

Volume 9, No. 1, 2017

ISSN (print) : 1858-4152

ISSN (online) : xxxx-xxxx

Homepage : http://journal.iaimsinjai.ac.id/index.php/al-qalam

\section{Kontribuasi Pembalajaran Holistik dalam Meningkatkan Minat dan Motivasi Siswa}

Pembalajaran holistik sangat berkontribusi dalam meningkatkan minat dan motivasi siswa karena dalam pembelajaran holistik membentuk manusia yang life long learners (pembelajar sejati). Dikatakan demikian karena dalam pembelajaran holistic menurut Surya:

1. Menerapkan metode belajar yang melibatkan partisipasi aktif murid, yaitu metode yang dapat meningkatkan minat dan motivasi murid karena seluruh dimensi manusia terlibat secara aktif dengan diberikan materi pelajaran yang konkrit, bermakna, serta relevan dalam konteks kehidupannya (student active learning, contextual learning, inquiry-based learning, integrated learning);

2. Menciptakan lingkungan belajar yang kondusif (conducive learning community) sehingga anak dapat belajar dengan efektif di dalam suasana yang memberikan rasa aman, penghargaan, tanpa ancaman, dan memberikan semangat yang menyebabkan meningkatkan minat dan motivasi belajar;

3. Memberikan pendidikan secara eksplisit, sistematis, dan berkesinambungan dengan melibatkan aspek knowing the good, loving the good, and acting the good; yang dapat mendorong meningkatnya minat dan motivasi belajar. ${ }^{30}$

Berdasarkan uraian di atas pembalajaran holistik sangat berkontribusi dalam meningkatkan minat dan motivasi siswa karena palam penyelenggaraannya murid dapat mengembangkan pemikiran dan perasaannya sebaik-baiknya sehingga makin mampu menguasai berbagai ilmu pengetahuan dan teknologi. Di samping

${ }^{30}$ Hendra Surya, Konsep Pembelajaran Holistik (Cet. I; Jakarta: PT Raja-Grafindo Persada, 2013), h. 121. 


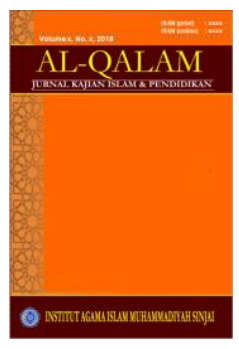

\section{AL-QALAM}

Jurnal Kajian Islam \& Pendidikan

Volume 9, No. 1, 2017

ISSN (print) : 1858-4152

ISSN (online) : xxxx-xxxx

Homepage : http://journal.iaimsinjai.ac.id/index.php/al-qalam

itu perkembangan murid secara individual juga ditumbuhkan rasa kebersamaan dengan sesama murid dan masyarakat pada umumnya. Dalam mempelajari segala macam ilmu pengetahuan ditumbuhkan kesadaran dan pengertian bahwa semua ilmu pengetahuan ada hubungannya satu sama lain karena semua berasal dari kehidupan manusia.

Pembalajaran holistik sangat berkontribusi dalam meningkatkan minat dan motivasi siswa karena dalam pembelajaran holistic memberikan menekankan pada keaktifan siswa. Pada dasarnya prinsip dari belajar adalah berbuat, berbuat untuk mengubah tingkah laku, jadi melakukan kegiatan. Tidak ada belajar kalau tidak ada aktivitas. Itulah sebabnya keaktifan merupakan prinsip atau asas yang sangat penting di dalam interaksi belajar-mengajar. Sebagai rasionalitasnya hal ini juga mendapatkan pengakuan dari berbagai ahli pendidikan.

Sardiman mengatakan bahwa tidak ada belajar kalau tidak ada aktivitas. Hal tersebut menunjukkan bahwa aktivitas merupakan prinsip atau asas yang sangat penting di dalam proses belajar mengajar. Jenis-jenis aktivitas dalam kegiatan pembalajaran holistik antara lain:

1. Visual activities (keaktifan melihat), misalnya: membaca, memperhatikan gambar, demonstrasi, percobaan, dan pekerjaan orang lain;

2. Oral activities (keaktifan langsung), seperti: menyatakan, merumuskan, bertanya, memberi saran, mengeluarkan pendapat, mengadakan wawancara, diskusi, dan interupsi;

3. Listening activities (keaktifan mendengarkan), meliputi: uraian, percakapan, diskusi, musik pidato;

4. Writing activities (keaktifan menulis), seperti: menulis cerita, karangan, laporan, angket, dan menyalin; 


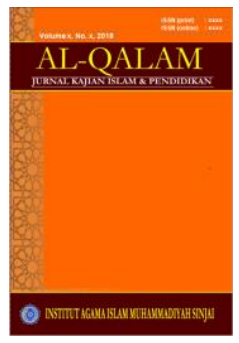

\section{AL-QALAM}

Jurnal Kajian Islam \& Pendidikan

Volume 9, No. 1, 2017

ISSN (print) : 1858-4152

ISSN (online) : xxxx-xxxx

Homepage : http://journal.iaimsinjai.ac.id/index.php/al-qalam

5. Drawing activities (keaktifan menggambar), misalnya: menggambar, membuat grafik, peta, dan diagram;

6. Motor aktivities (keaktifan motorik), seperti: melakukan percobaan, membuat konstruksi, model mereparasi, bermain, berkebun, dan beternak;

7. Mental activities (keaktifan mental), misalnya: menganggap, mengingat, memecahkan soal, menganalisa, melihat hubungan, dan mengambil keputusan;

8. Emosional activities (keaktifan emosi), seperti: menaruh minat, merasa bosan, gembira, bersemangat, bergairah, berani, tenang, dan gugup. ${ }^{31}$

Pembelajaran holistic sangat efektif meningkatkan minat dan motivasi belajar siswa karena pembelajaran holistik merangsang pertumbuhan kreativitas pribadi, dan keingintahuan dengan cara berhubungan dengan dunia. Dengan demikian anak didik dapat menjadi pribadi-pribadi yang penuh rasa ingin tahu yang dapat belajar apapun yang mereka butuh ketahui dalam setiap konteks baru.

Pembelajaran holistic dikatakan efektif meningkatkan minat dan motivasi belajar siswa karena pembelajaran holistik, karena dalam pembelajaran holistic memiliki ciri-ciri sebagai berikut:

1. Pembelajaran diarahkan agar siswa menyadari akan keunikan dirinya dengan segala potensinya.

2. Pembelajaran tidak hanya mengembangkan cara berpikir analitis/linier tapi juga intuitif.

3. Pembelajaran berkewajiban menumbuhkembangkan potensi kecerdasan ganda (multiple intelligences).

4. Menyadarkan anak akan keterkaitannya dengan komunitas sekitarnya

\footnotetext{
${ }^{31}$ Sardiman AM, Pembelajaran Holistik (Cet. XII Jakarta: Gramedia, 2013), h. 130.
} 


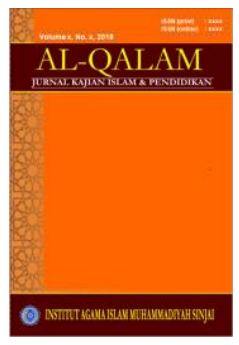

\section{AL-QALAM}

Jurnal Kajian Islam \& Pendidikan

Volume 9, No. 1, 2017

ISSN (print) : 1858-4152

ISSN (online) : xxxx-xxxx

Homepage : http://journal.iaimsinjai.ac.id/index.php/al-qalam

5. Memperhatikan hubungan antara berbagai pokok bahasan dalam tingkatan transdisipliner, sehingga hal itu akan lebih memberi makna kepada siswa.

6. Mengajak anak menyadari hubungannya dengan bumi dan ciptaan Allah selain manusia seperti hewan, tumbuhan, dan benda (air, udara, tanah) sehingga mereka memiliki kesadaran ekologis.

7. Menghantarkan anak untuk menyeimbangkan antara belajar individual dengan kelompok (kooperatif, kolaboratif, antara isi dengan proses, antara pengetahuan dengan imajinasi, antara rasional dengan intuisi, antara kuantitatif dengan kualitatif

8. Pembelajaran yang tumbuh, menemukan, dan memperluas cakrawala.

9. Pembelajaran yang merupakan sebuah proses kreatif dan artistic

Pembelajaran holistic sangat efektif meningkatkan minat dan motivasi belajar siswa karena membantu mengembangkan potensi individu dalam suasana pembelajaran yang lebih menyenangkan dan menggairahkan serta dapat memperoleh kebebasan psikologis dan emosionalnya.

Pembelajaran holistik dikemas bukan dalam bentuk yang kaku melainkan melalui hubungan langsung antara anak didik dengan lingkungannya. Pendekatan Holistik tidak melihat manusia dari aktivitasnya yang terpisah pada bagianbagian tertentu, namun merupakan mahluk yang bersifat utuh dan tingkah lakunya tidak dapat dijelaskan berdasarkan aktivitas bagian-bagiannya. Tidak hanya melalui potensi intelektualnya saja, namun juga dari potensi spiritual dan emosionalnya.

Proses pelaksanaan pembelajaran holistik dalam pendidikan akan mengajak anak berbagi pengalaman kehidupan nyata, mengalami peristiwaperistiwa langsung yang diperoleh dari pengetahuan kehidupan. Dengan demikian pendidik diharapkan dapat menyalakan/menghidupkan kecintaan anak akan 


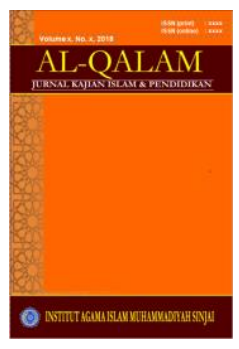

\section{AL-QALAM}

Jurnal Kajian Islam \& Pendidikan

Volume 9, No. 1, 2017

ISSN (print) : 1858-4152

ISSN (online) : xxxx-xxxx

Homepage : http://journal.iaimsinjai.ac.id/index.php/al-qalam

pembelajaran. Pendidik juga mendorong anak untuk melakukan refleksi, diskusi daripada mengingat secara pasif tentang fakta-fakta.

Pembelajaran holistik sangat berkontribusi meningkatkan minat dan motivasi siswa karena dalam pembelajaran holistic memberi kebebasan anak didik untuk mengembangkan diri tidak saja secara intelektual, tapi juga memfasilitasi perkembangan jiwa dan raga secara keseluruhan sehingga tercipta manusia Indonesia yang berkarakter kuat yang mampu mengangkat harkat bangsa.

Pembelajaran holistik mengembangkan keragaman strategi pembelajaran untuk memenuhi kebutuhan siswa; 2) dalam pembelajaran holistik membantu siswa untuk mengembangkan potensinya; 3) dalam pembelajaran holistic menyusun lingkungan pembelajaran yang dapat mengembangkan seluruh potensi siswa; dan 4) dalam pembelajaran holistik mengimplmentasikan strategi penilaian yang beragam.

\section{SIMPULAN}

1. Konsep dasar pembelajaran holistik (holistic learning) yaitu pendekatan pembelajaran yang berfokus pada pemahaman informasi dan mengkaitkannya dengan topik-topik lain sehingga terbangun kerangka pengetahuan. Pembelajaran holistik memandang manusia secara utuh, dalam arti manusia dengan unsur kognitif, afeksi dan perilakunya. Manusia juga tidak bisa berdiri sendiri, namun terkait erat dengan lingkungannya. Dalam pembelajaran holistik, diterapkan prinsip bahwa siswa akan belajar lebih efektif jika semua aspek pribadinya (pikiran, tubuh dan jiwa) dilibatkan dalam pengalaman siswa. Pembelajaran holistik membangun manusia secara keseluruhan dan utuh dengan mengembangkan semua potensi manusia yang mencakup potensi 


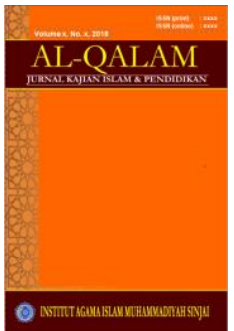

\section{AL-QALAM}

Jurnal Kajian Islam \& Pendidikan

Volume 9, No. 1, 2017

ISSN (print) : 1858-4152

ISSN (online) : xxxx-xxxx

Homepage : http://journal.iaimsinjai.ac.id/index.php/al-qalam

sosial-emosi, potensi intelektual, potensi moral atau karakter, kreatifitas, dan spiritual.

2. Konsep dasar minat dan motivasi belajar siswa yaitu minat merupakan potensi psikologi yang dapat dimanfaatkan untuk menggali motif tersebut, apabila seorang peserta didik sudah termotivasi untuk belajar, maka peserta didik tersebut juga akan melakukan aktivitas belajar secara maksimal.

3. Pembalajaran holistik sangat berkontribusi dalam meningkatkan minat dan motivasi siswa sangat karena pembelajaran holistik mengandung kesatuan pendidikan jasmani-rohani, mengasah kecerdasan intelektual-spiritual (emosional)- ketrampilan, kesatuan materi pendidikan teoritis-praktis, kesatuan materi pendidikan pribadi-sosial-ketuhanan. Juga tidak melihat manusia dari aktivitasnya yang terpisah pada bagian-bagian tertentu, namun merupakan mahluk yang bersifat utuh dan tingkah lakunya tidak dapat dijelaskan berdasarkan aktivitas bagian-bagiannya. Tidak hanya melalui potensi intelektualnya saja, namun juga dari potensi spiritual dan emosionalnya.

\section{DAFTAR PUSTAKA}

Daradjat, Zakiah dkk. (2004). Ilmu Pendidikan Islam Cet. V; Jakarta: Bumi Aksara,

Deppennas. (2008). Perangkat Penilaian Pembelajaran Cet. I; Jakarta: Badan Pengembangan Sumber Daya Manusia Pendidikan dan Kebudayaan dan Penjaminan Mutu Pendidikan,

Dimyati dan Mudjiono. (2009). Belajar dengan Pendekatan Baru Cet. II; Bandung: Remaja Rosdakarya, 


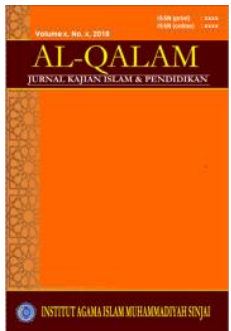

\section{AL-QALAM}

Jurnal Kajian Islam \& Pendidikan

Volume 9, No. 1, 2017

ISSN (print) : 1858-4152

ISSN (online) : xxxx-xxxx

Homepage : http://journal.iaimsinjai.ac.id/index.php/al-qalam

Gie, The Liang. (1980). Cara Belajar yang Efektif Yogyakarta : Universitas Gaja Mada,

Halida, (2015). Penerapan Model Networked (jejaring) dalam Pembelajaran Terpadu Pendidikan Anak Usia Dini, Cet. VII; Pontianak: Ilmu Pendidikan FKIP UNTAN,

Hamalik, Oemar. (2003). Kurikulum dan Pembelajaran Cet. IV; Jakarta: Bumi Aksara,

Haling, Abdul. (2006). Belajar dan Pembelajaran Cet. I; Makassar: Badan Penerbit Universitas negeri Makassar,

Luthans, Bower. (2005). Motivation-Requiretment Hirarchy By Maslow. McgrawHill Inc. Tokyo,

Madjid, Abdul. (2005). Perencanaan Pembelajaran (Mengembangkan Standar Kompetensi Pendidik) Cet. I; Bandung: Rosda Karya,

Muhaimin, et al, (2004). Paradigma Pendidikan Islam, Upaya Mengefektifkan Pendidikan Agama Islam di Sekolah Cet. III; Bandung: Remaja Rosda Karya Offset,

Republik Indonesia, 2003)."Undang-undang RI. Nomor 20 Tahun 2003 Tentang Sistem Pendidikan Nasional", dalam Redaksi Sinar Grafika Cet. 1; Jakarta : Sinar Grafika,

Sardiman A.M., 2001). Interaksi dan Motivasi Belajar Mengajar Cet. IX; Jakarta: CV. Rajawali, -, (2013). Pembelajaran Holistik Cet. XII Jakarta: Gramedia,

Slameto, (2003). Belajar dan Faktor-faktor yang Mempengaruhinya Cet. IV; Jakarta: PT. Rineka Cipta,

Sofyan, Herminarto. dan Hamzah B. Uno, (2004). Teori Motivasi dan Aplikasinya dalam Penelitian Cet. II; Gorontalo: Nurul Jannah,

Sudrajat, Akhmad. Pendekatan Pembelajaran Holistik di Sekolah Dasar, (Cet. IX., Jakarta: PT Raja Grafindo Persada, 2014). 


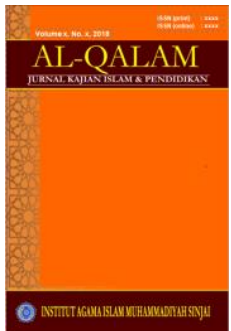

\section{AL-QALAM}

Jurnal Kajian Islam \& Pendidikan

Volume 9, No. 1, 2017

ISSN (print) : 1858-4152

ISSN (online) : xxxx-xxxx

Homepage : http://journal.iaimsinjai.ac.id/index.php/al-qalam

Sugandi, Achmad. (2007). Teori Pembelajaran Cet. V; Semarang: UPT UNNES,

Suryabrata, (2002). Psikologi pendidikan Cet. XI., Jakarta : PT Raja Grafindo Persada,

Surya, Hendra (2013). Konsep Pembelajaran Holistik Cet. I; Jakarta: PT RajaGrafindo Persada,

Trianto, (2008). Mendesain Pembelajaran Kontesktual di Kelas Cet. I; Jakarta: Cerdas Pustaka Publisher,

Usman, Basyiruddin. (2002). Metodologi Pembelajaran Agama Islam Cet. I; Jakarta: Ciputat Pers.

Winkel, W.S. (2004). Psikologi Pendidikan dan Evaluasi Belajar Cet. XIII; Jakarta: Gramedia. 